\title{
A LANGUAGE THAT FORGOT ITSELF (ESSAY ON THE CURIOUS NON-EXISTENCE OF GERMAN AS A RECOGNIZED MINORITY LANGUAGE IN TODAY'S POLAND)'
}

\section{ABSTRACT}

This essay draws on my almost three decades worth of research on the multiethnic and multilingual history of Upper Silesia during the last two centuries, when various ethnolinguistic nationalisms have radically altered the ethnic, political, demographic and linguistic shape of the region. I focus on the German minority that was recognized in Poland in the early 1990s. This recognition was extended to the German language. However, though in official statistics there are hundreds of schools with German, and bilingual signage amply dots the Upper Silesian landscape, neither in the region nor elsewhere in Poland is there a single, however small, locality where German would be the language of everyday communication.

With this essay I attempt to explicate this irony of official recognition on the one hand, and the tacitly enforced non-existence on the ground, on the other hand.

Key words: ethnolinguistic nationalism; German speech community in post-1945 Poland; minority language rights; Upper Silesia

\section{-.....}

1 As always, I am indebted to Michael O'Gorman for his loving care extended for the sake of polishing the rough edges of my prose. I also thank Catherine Gibson and Michael Moser for their valuable suggestions and corrections.

This is an Open Access article distributed under the terms of the Creative Commons Attribution 3.0 PL License (creativecommons.org/licenses/by/3.0/pl/), which permits redistribution, commercial and non-commercial, provided that the article is properly cited. (C) The Author(s) 2014.

Publisher: Institute of Slavic Studies PAS [Wydawca: Instytut Slawistyki PAN] 
Streszczenie

W eseju snuję refleksję nad procesami, za pomocą których de facto zakazano i zniesiono użycie języka niemieckiego na Górnym Śląsku, którego całość przypadła Polsce po II wojnie światowej. Niewysiedloną do Niemiec (na zachód od linii Odry i Nysy) ludność miejscową, odgórnie określaną jako "autochtoni", zatrzymano po to, by "udowodnić odwieczną polskość” tego regionu. Po roku 1989, w wyniku demokratyzacji życia społecznego i politycznego, władze uznały trwanie znacznej grupy tej populacji i jej dążeń do niemieckości oraz zezwolity na utworzenie mniejszościowego systemu oświaty. Lecz status mniejszości i szkoły „niemieckie” (niestety, tylko z nazwy) nie przełożył się na rewitalizację użycia języka niemieckiego, którym n i e mówi się w życiu codziennym w żadnej, nawet najmniejszej miejscowości w dzisiejszej Polsce. Językiem codziennej komunikacji mniejszości niemieckiej nw Górnym Śląsku pozostaje śląszczyzna, dzielona w tej funkcji z innymi Ślązakami.

Słowa kluczowe: Górny Śląsk; język niemiecki; język śląski; Niemcy; Polska; mniejszościowa polityka językowa; oświata mniejszościowa

T he mystery persists. In the entry devoted to Poland in the respectable reference on the languages of the world, the Ethnologue, the number of native-speakers of German living in the country is conservatively estimated at half a million („Poland: Languages", n.d.). Until well into the 1990s German sources spoke of one million or a million and a half Germans in Poland. It is noted that the region where they live in compact areas of settlement is the countryside of Upper Silesia.

Silesia Superioris, Oberschlesien, Haute-Silésie, Horní Slezsko, Górny Śląsk, FelsőSzilézia - it is known by so many names, as many homelands in Central Europe were before the powers that be minced and fitted this part of the continent into the unbecomingly tight and too-small pantyhoses of national polities, each so pure, through and through homogenous, so painfully monolingual. Each, a country of a single tongue, jealously guarded against encroachments by the neighbors' enemy idioms. Every capital was loudly disavowing foreign imposters stealthily laying a claim to its national language. The nation-state's monolingual monopoly on its own language was the mantra that seized the day in the twentieth century. The gospel of cuius regio, eius lingua spread rapidly, like steppe fire, and still holds Central Europe as its enthralled captive, the Europe that ceased to be able to see further than the tip of the unquiet muscle dancing in its mouth.

Yeah, I remember, I was born in Upper Silesia, or Ślōnsk, as the region's natives refer to their homeland. Today it lies mostly in Poland, extending from Opole to Katowice, while its southern sliver straddles the border and unrolls itself into the north-east of the Czech Republic, between Opava and Ostrava. Nuances can be multiplied. The past is like a never-ending desert. Innumerable grains of its fine, powdery sands add and add to each other, with the false promise of the true history waiting to emerge just round the corner, when the last crucial fact has at last been found and placed in the completed store of knowledge.

In the end, fog mists the spectacles adorning the moist brow of a patient and diligent scholar. Shhhh... he sees nothing, tiredness overtakes her, and s-he retires. The past is a foreign land, in essence unknowable, like the human world itself. No one can meet all 
the other humans in the world: even after a long night spent talking and swigging glasses filled to the brim with beady-cold vodka, nobody can peer into the depths of their souls. Ants, for all their diminutive stature, are incapable of noticing Dubai's Burj Khalifa in its full glory, but unknowingly may scale this skyscraper's lower floors in search of food and shelter.

So there is hope; all is not lost.

In the depths of the nineteen seventies, I was a small boy running on the undulating pasture that began where the pine forest on the hill near Chemik Cinema stopped. It extended to the housing estate of almost-stately four-family houses built for the staff of the local power plant by the not-yet-shoddy prewar architects twenty years earlier. Friends called out to me; people in the street answered my polite greetings, which Mum had taught me to utter. It was she who shouted her heart out calling me to come back home when night was falling. All their tongues worked on and on. We talked, or else we sulked and didn't.

Never did I have a need for naming the medium through which we channeled these exchanges. It was Mr Chyłek, sunbathing on a deckchair in one of the gardens at the back of our house, who pronounced that it was my last carefree summer, and soon some strange 'edukeishn' would commence and seize me for good. A word as fearsome and threatening as 'riting.' I realized that something was the matter when the word 'school' began to pop up with increasing frequency in reference to myself, after I had turned five. In quieter moments before sleep, or after church, on a lazy Sunday afternoon, Mum would take me aside and keep telling me, 'You don't say koło but rower, ${ }^{1}$ not dej se karnōnć but daj się przejechać, ${ }^{2}$ not Ŏma...'

'Mum, but I have Öma.'

'Yes, but say Babcia, ${ }^{3}$ instead.'

'Will Ŏma know I'm talking to her, when I call her Babcia?'

'Well, you can always call her Öma.'

'Why, why should I call her Babcia, then?'

'One day, you'll understand. Please, repeat after me...'

And indeed, I understood soon enough. After starting school, from one day to the next, my friends and I, who played hide-and-seek, wargames, or cops and robbers, had to cease saying jŏ for 'l,' because in 'correct Polish' it was ja. So now we knew we spoke 'Polish,' and had to speak it 'correctly,' because what we had uttered up to now was some 'filthy corrupted Polish,' the teacher informed us gently and convincingly. In no time our language was straightened out in our mouths, leaving us in rather straitened circumstances: 'Jacek! Dej se karn...'

'What d'you want, Tomek?'

'I mean "daj sie przejechać," gut?'

'The teacher said we can't say "gut," only "dobrze," remember?'

We almost stuttered. Talking in inverted commas before we were even able to write caused us difficulty. The invisible punctuation marks sliced the happy yarn of our voices into sentences and paragraphs. A block of spoken text for a penny a kilo. The heavy brick failed to fly, at best flapping its stunted wings heavily before keeling over in a puddle. Silences grew. They weren't just moments of panting to catch your breath after a quick sprint to the competitive call 'Who's going to be first to the old pear tree?' Our silences grew longer and heavier, pregnant with the meaning of the unsaid. It became impossible to yell a call to play another game when you fancied it. Before yelling you thought how to say it, and often dropped the matter altogether, or lowered the volume of your previously 
happy yell to drown out the finer points of pronunciation. 'Tomek, don't mumble. Say clearly what you want!'

Many things - all of a sudden - became unsayable, because the teacher hadn't told us how to say them yet. This predicament didn't touch kids who spoke - we now knew - Polish, the plain Polish with no need for the word 'corrupted' to stand in front of it. It was a revelation. They played with us now just as they did before, and talked as freely as ever. School didn't in the least impede their tongues, but it knotted ours. Who wants to be laughed at for speaking 'incorrectly,' like a villager, especially if you are from a family of farmers?

Our relatives lived at the end of a meandering road in a hamlet by a lake, or in cities, out of view, in the shadows of a colliery shaft or a steelworks, under the sheltering sky of a workers' self-contained red-brick housing estate with allotment gardens at the perimeter, in familioki, or low-rise eight-to-twelve-family houses with communal toilets on the mid-floors. The ungainly sight of our relatives' settlements was not allowed to offend the progressive reality of the 'really existing socialism' that unfolded in orderly strings of tenstore blocks of flats and in the form of state farms, or PGRs, as the Polish acronym had it.

The unsayable was left alone by the engineers of human souls and lives, when it didn't dare more than to murmur, practically inaudibly. Uttering it, or let alone yelling the unsayable at the top of your lungs, as children not yet touched by schooling do, was not done. Good manners required either silence or murmur. No one wanted to be left out in the rain at a station of backwardness, while the slick train of progress was darting forward, towards a bright tomorrow.

But some couldn't help it, and when they thought they were among their own, they greeted one another with a cheerful guten Morgen or a wistful szczynść Boże. ${ }^{4}$ Old women - always old women - in village shops operated antiquated scales and cash registers with unusual Blackletter inscriptions on them, machines which declared that they had been manufactured in such antediluvian and forgotten cities as Gleiwitz or Breslau, or far-away destinations of popular desire, hidden beyond the Iron Curtain, like Frankfurt am Main or the Free and Hanseatic City of Hamburg.

Freedom was in short supply. No surprise, really, in an economy of scarcity. Ration cards, which had been introduced across the length and breadth of Europe during the Second World War, stayed in communist Poland until the mid-1950s, and then crept back later. Their return after two decades was at first innocuous, with a single ration card for sugar. Then the dam burst, and an avalanche of multiple cards for all kinds of goods and services engulfed the country until the end of the communist system in 1989. Life was dominated by queues and the frustration that neither money nor the ration cards were good for anything. Their supposedly enabling combination evoked just a shrug when, after standing in a line for hours on end, you reached the shop counter only to be told that the stock had already sold out.

The item in the shortest supply of all was the passport, especially its rarer subspecies entitling the holder to travel to the West, to scale the geopolitical fault of the Iron Curtain on the way to West Germany. Going to the Rajch (Silesian for Reich, a shortened version of the pre-1945 official name of Germany, Großdeutsches Reich, or the 'Greater German Empire') sounded to our ears like ascending straight to heaven, to paradise, which is raj in Slavic, so tantalizingly close to Rajch. Only the most fortunate few and far between got the grace of salvation by state-rationed salvation-by-emigration. Impetuous individuals, tired of waiting for the state's stately consent, left on a short visit to their relatives in 
West Germany, and forgot to return. Families were split. Wives with children withered for five years waiting to be let out, yearning for reunion with their long unseen husbands in Bochum or Essen. What if, tired of the unavoidable wait, imposed by the offended regime, they had already remarried in Rajch?

The rationing of freedom didn't apply to people Warsaw wanted to be rid of. In no time at all they were stripped of their citizenship, issued with exit travel documents, and packed onto trains leaving for Vienna, or on board ferries bound for Malmö. This fate was meted out to Poland's Jews in 1968, and - what is unjustifiably much less known - in 1981, to Roma from Oświęcim. The town's wartime name of Auschwitz retains its sinister feel, and its inhabitants were true to it. In the course of the pogrom of the local Roma in 1981, they founded a grassroots Committee for Expelling the Gypsies (Komitet na Rzecz Wypędzenia Cyganów) from their town (Isztok, 2010). The authorities relented in the face of this popular pressure. Poland was for Poles only, wasn't it? Can you be really a Pole, if you don't speak correct Polish? The obvious answer is terse and to the point, 'Of course, not.'

What about the old female shop assistants in village shops? When buying a lollipop with my pocket money, I overheard them counting, under their breath, and doing sums in the same numbers as those repeated by Ŏma: ein, zwei, drei, vier... in German, or ańć, cwajf, trzi, sztyry... in Silesian. In school the teacher told us that in proper Polish we must say: jeden, dwa, trzy, cztery..., and nothing else. 'Understood?'

'Yes, Ma'am - Tak, psze Pani' - we replied obediently in correct Polish.

Ŏma spoke Silesian to Mum and she replied in Polish. On rarer occasions we wouldn't understand Dad when he exchanged a couple of German sentences with Ŏma, which never failed to irk Mum. Mum and Dad worked full-time, and Ŏma helped them out when she visited by taking care of my brother and me. I was a sickly child, so they were afraid of sending me to a crèche, and even when I was a bit older, the local kindergarten was short of places. Ŏma did the shopping and cooked for us. Mum dictated in Polish what to buy at the market. Ŏma repeated in Silesian, not to miss an item due to a misunderstanding, and she wrote her list down in German, in her exquisite hand. In the hand no one could read any more, because it was cursive Fraktur (a form of Blackletter). It was not taught in German schools after 1941, when Adolf Hitler had denigrated it as 'Swabian Jewish letters,' and banned it in favor of the 'normal' Antiqua script.

In school I learned to write exclusively in 'normal letters,' but learning how to speak 'normally' in Polish took longer. Much longer. My choice of words, their pronunciation, my construction of sentences, my accent all continued to appear to teachers to be ever so slightly 'incorrect,' 'imperfect' and 'faulty.' The holy grail of 'real' Polish eluded me. Mum and Dad wondered why, since I was a bookish child and read so much. Dad too read a lot, yet Mum never tired of correcting his inflectional endings, admonishing him, 'Take care, because Tomek will end up speaking like you.' Well, how could I speak differently from them, taking in equal measure from Dad and Mum? I was their son, after all.

Another mystery of my school years was the annual disappearance of friends. Every September, when we congregated after the summer holidays for the start of the new school year, invariably someone was missing. We asked quietly 'Where is Sylwia?,' 'Where did Achim go?' The teachers didn't explain and carried on as usual. Then, shortly before Christmas a beautiful card would arrive, with a snowman and a colorful Christmas tree - all candles and decorations - depicted against a winter landscape emphasized 
with silvery embossments. They had left for Rajch, in secret, so that the security police would not stand in their way. Their parents had it good in Poland. As docile and agreeable citizens of the people's democracy they weren't on the authorities' radar. Playing blasé tourists on their way to the Yugoslav riviera, they slipped surreptitiously to the other side of the Iron Curtain. No surprise. Who wouldn't if they could, to escape the nightmare of shortages, waiting lines and the dreary single television channel dominated by the single party's general secretary and his coterie? The daily reverie wrapped up at $11 \mathrm{pm}$ with the Polish national anthem, in a state whose government and military forces were directly answerable to the Kremlin.

With time, with the policy of détente and the hard currency loans eroding the tightness of the Cold War division, my 'disappeared' friends and relatives started coming back to Poland for visits. They looked and smelled differently, wearing colorful clothes and washing their hands with Fa soap, all unimaginable luxuries to us. They happily handed out to us Donald bubble gums and West German sweets. Eavesdropping on adults, I heard that my relatives from Rajch had signed up for membership with Polonia, the state-sponsored Polish organization for Poles living abroad. This shrewd move allowed them to exchange their Deutschmarks for zloties at a much better rate than that set by the Polish National Bank. At that time, an average monthly salary, exchanged on the black market, didn't add up to more than seven dollars or fourteen Deutschmarks.

When talking, the adults swam from German to Silesian to Polish, vodka on the table smoothing and quickening the transitions. Our former schoolmates, already going to German schools, confused the genders of Polish words, replaced them with German ones, and they outshone us with their ease and apparent sophistication. They could talk their heads off in Silesian, not giving a jot about the Polish teacher, their tongues unknotted and free again. But on their return to Rajch, they weren't so happy. In rare moments of honesty they complained of their German teachers ridiculing their Wasserpolnisch, or 'Polish-German.' The Silesian language wasn't appreciated in either Poland or Germany.

Never in my life have I heard people speaking German in Upper Silesia in the street. Neither there nor elsewhere in today's Poland is there a single locality, however small, whose inhabitants speak to one another in German. That language is nowhere to be heard in daily life. It is gone. Period. How come? Where is this teeming multitude of half a million German-speakers from the Ethnologue?

Together with Artur from the village of Zakrzów, I attended secondary school. He was a quiet, hard-working boy, his Polish as 'corrupted' as mine. Twenty-six years after finishing school, during a class reunion in the Spring of 2012, he told me a story that was an eye-opener. In the mid-1980s a venturing photographer traveling on foot and by bus paid his family a visit. His father, who could have taken a firmer stance, was away, working. His mother busied herself with dinner, and (what else?) talked to her children. All the picture of domestic bliss. But they spoke in German, as they always did in private. Mother made sure to pass this language on to her children. Father spoke only the 'corrupted Polish' needed to survive at school.

The photographer was slow in offering to take a picture of the family. The atmosphere was getting tense. Artur regretted that Mother had allowed the stranger in and served him a glass of tea on the large Sunday table in the guest room. The camera looked old and hardly used at all. The photographer's fingers, instead of nimbly operating the knobs, buttons and filters, stayed away from them. The man said to Mother, 'They say you speak German at home.' 


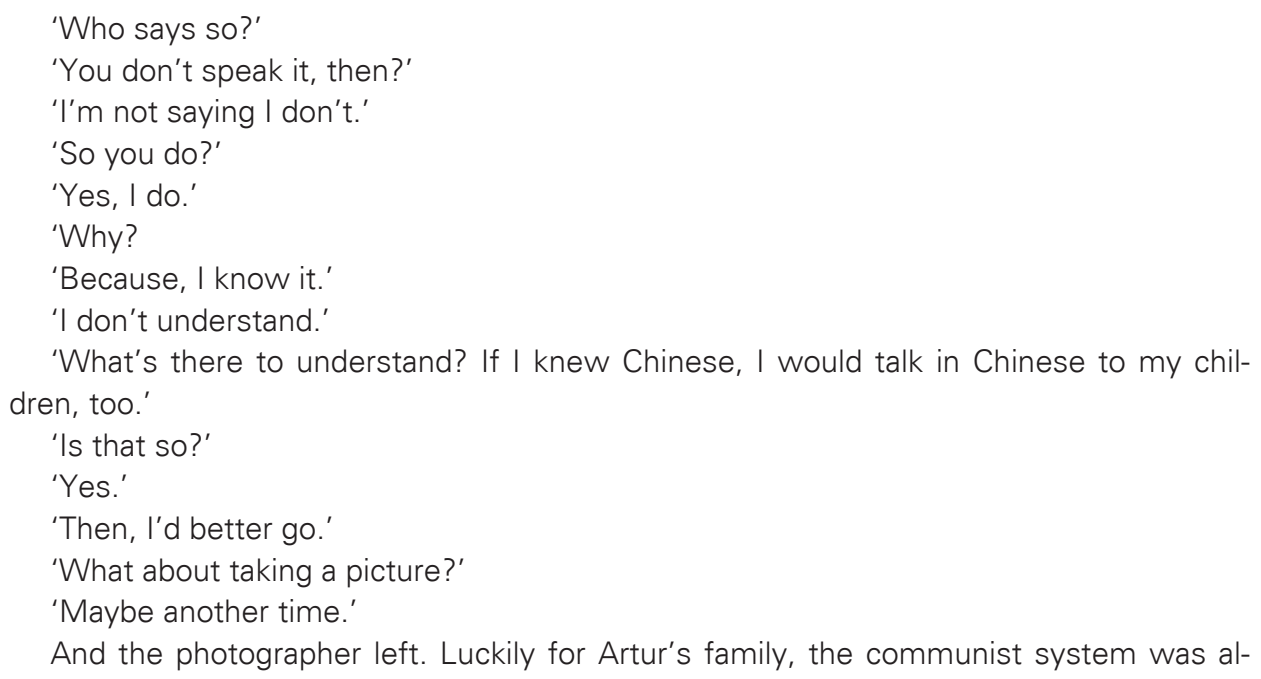

And the photographer left. Luckily for Artur's family, the communist system was already in its death throes. Poland was strangled by a half-decade-old trade embargo and a never-ending economic crisis. He dared to tell me the story only now, almost three decades later. Such was the fear of an unexpected visit paid by a smutny pan, or 'sad gentleman,' as we euphemistically called plainclothes security officers.

Scholars from all over the world zeroed in on newly free Poland in the early 1990s. Their Polish colleagues woke up from the stupor that had been clamped on them by the sole party's correct line and began probing into all kinds of social issues. Not a single one of the myriads of sociological polls was devoted to the fear felt by Upper Silesia's inhabitants who speak 'incorrect Polish.' It took a team from the Japanese University of Osaka to sound out the depths of this fear in 2009. It turned out that even today, a tenth of Poland's Germans report being discriminated against just because they are Germans. During the communist years the number was sixty per cent and more, as the survey found by interviewing the oldest generation. That is why, out of fear, most didn't argue with civil servants who imposed 'pure Polish' first and last names on them (Badanie Socjologiczne Mniejszości Niemieckiej w Polsce, 2010, pp. 22, 25). Martin Grögier became 'Marcin Grygier,' Johannes Schmidt - 'Jan Kowalski,' and Heinrich Kroll - 'Henryk Król.' This Polonizing action, following in the tracks of the earlier changes in the names of villages, towns and cities (Brieg was made into 'Brzeg,' Leobschütz into 'Głubczyce,' or Oppeln into 'Opole'), tore away the 'German façade' from the 'timeless Polishness of Upper Silesia.'

Claiming this façade as your heritage was tantamount to a 'traitorous breach' of Poland's very raison d'état. When my daughter was born in 1990, naively believing that liberty had arrived after the fall of communism, I wanted her name to appear as 'Annamarie' on the birth certificate. The official in the Registry of Births of Kędzierzyn-Koźle municipality reddened in the face upon hearing my modest request.

'It is not a Polish name,' she shot back.

'So maybe "Marie" alone would be acceptable?'

'Well, it is not Polish, either.'

'I know, it is of Hebrew origin.'

'My young man, don't play games with me. You know what I mean.'

'Then, perhaps, we could agree on "Annamaria," if the tiny final " $e$ " offends so much.' 
The registrar didn't bother to answer and brusquely handed me a well-thumbed booklet 'The Official List of Slavic Names that May be Used for Naming Children.' I settled for 'Anna Maria,' neither having the time nor the money for a struggle in court. Fear might have played a role, too. My daughter needed a name to get the documents needed to access the healthcare system, for my wife to get maternity leave, and so that the state would pay us child benefit. A nameless child wouldn't do.

Four years later I tried again. I convinced my parents that we should return to the original spelling of our surname from the one Polonized by fiat to 'Kamuzela' in 1947. (It wasn't that the Polonized version wasn't without its uses. When talking over the phone in South Africa, my interlocutors often thought I was a Bantu, because my family name vaguely reminded them of a Setswana word.) All our documents were affected by the change, and we ended up going to various offices to have our certificates and identity cards updated. It was such a monotonous and wearying experience that when I was doing this in a revenue office, I thought I had begun hearing voices in my head - a bad sign. But no, the lady at the desk attending to my name on the tax roll was an experienced ventriloquist wasting away in this den of an office. Just barely audibly, through her clenched teeth, and not for a moment raising her eyes from the papers on which she was scribbling away, the civil servant said, 'You all should have left this place.'

A noble and humane wish indeed. At the Potsdam Conference in the wake of the Second World War, Clement Attlee, Joseph Stalin and Harry Truman, all insincere smiles while striving to outmaneuver one another, granted the Kremlin its wish to pass most of the German lands east of the Oder-Neisse line to Poland. Stalin had no desire to surrender the eastern Polish territories he had gained earlier when he had been buddies with Hitler before 1941, on the basis of the August 1939 Ribbentrop-Molotov secret protocol that had split Central Europe between the Soviet Union and Germany. The Poles could grudgingly agree to the imposition of the communist system on them, but not to a smaller Poland. A complication was the Germans living east of the Oder River. Warsaw wouldn't want to keep them, because then Poland would have become a state with a forked tongue, a reptilian possibility to be avoided. Stalin curled his mustache knowingly, and revealed to his companions that almost all the Germans had already fled before the advancing Red Army. At most, according to him, four hundred thousand stayed put.

This hurdle out of the way, Attlee and Truman agreed to the 'orderly and humane transfer' of the rest to a yet-undefined postwar Germany. The map of their state was torn away from under the very feet of the Germans who in the summer of 1945 woke up in a country that unbeknownst to them had already ceased to be theirs. The foundations of their houses were not heavy enough and the topsoil on their diligently tilled fields was not thick enough to keep this map, furled and unfurled by gusts of the wind of history, pinned firmly to the ground. It flew away straight into the blue sky, as all human thoughts and ideas have a tendency to do. The map made itself comfortable on the other bank of the Oder, and had no intention of coming back.

What for? The Oder had already morphed into the Polish river Odra, and the Neisse turned out to be the ur-Slavic Nysa. Further east, Poles in Grodno, Lwów and Wilno suffered the same cartographic predicament. The plates of the political atlas of Europe had run amok. For half a year they had already been streaming from what were no longer their cities of Hrodna, Lviv and Vilnius to the new brave Polish cities of Gdańsk, Szczecin and Wrocław, whose German inhabitants couldn't feel at home there any more, their old Danzig, Stettin and Breslau hitching a ride home on the clouds, westward ho! 
The expulsions of Germans and Poles were anything but orderly and humane. How could they be? Millions of the old, young, infirm and pregnant were chased away in a matter of months in the dead of winter. Hungry and starving, wasting away in urban ghettos and transition concentration camps, they had no shelter against rain and sleet. They were barefoot on the muddy road. No water was given to them when relentless sunshine burned them. They succumbed to tiredness, typhoid fever and death. 'Served them right..., Served them right...', the same self-justifying explanation of surprising and mysterious leniency toward the 'war-mongers' was repeated time and again - collective responsibility seized the day. And on their arrival, the 'transferees' found out that they were still not at home. It took them decades to make the new places into home, to gain their neighbors' trust. At first the neighbors didn't want to have anything to do with the 'rabble from the east, reeking of Slavs.'

In West Germany, the expellees became known as Aussiedler, or 'resettlers.' Bureaucrats have an inexhaustible capacity to sanitize with bland words the unbearable realities that make the inconsolable howl skyward, from the depths of their hearts, when faced with inhuman suffering and misery inexpressible in words. 'Repatriates' (repatrianci), 'those returning to their patria,' to their 'own' country, was what Warsaw called the Polish expellees trundling westward from what had already become part of the Soviet Union. The irony was lost on the civil servants, impatient with the unceasing 'human flow, ' which made them work inordinately long hours. 'Hurry up!,' 'Don't complain!,' 'Listen to me!', 'You're giving birth? No problem, ask your mother to help you with the delivery.'

'But she died in Tarnopol.'

'There isn't a city of that name. Move on!'

A shrunken emaciated man is on a makeshift stretcher made from a wooden trough, his unseeing eyes peering beyond the blue of the sky. His wife kneeling at the feet of the station-master begs 'Let us get off the train here. He's dying.'

'Well, he's still alive now.'

'As good as gone, his hours are numbered. Sir...'

'There're no lords in the new People's Poland, remember!'

'Please...'.

'Stay where you are! There are cemeteries galore in every locality ahead.'

You cannot know the lot of your neighbor, unless you experience the same tragedy that befell her.

The Polish communist government decided not to expel all the Germans. There were not enough 'repatriates' to re-populate the newly 'former' German towns and villages. In an early effort to improve the international image of the new People's Poland, ghost hamlets in the Sudeten Mountains were flattened with dynamite and their names erased from the maps. The Germans who were retained in Poland couldn't be German, so they - like the 'former' German cities - were renamed, and thus became 'autochthons' (autochtoni). The label, sonorous and hygienically Greek in origin; autochthons became characters in this classical tragedy of loss without hope of redemption, the Western Allies and the Soviet Union acting as the chorus. Indeed, in the former German lands taken over by the new Poland, only the autochthons were locals, indigenous to their regions. It was everybody else who was a newcomer.

In the bureaucratic newspeak, an 'autochthon' turned out to be a 'Pole not fully aware of his Polishness that must be reawakened in him by the state.' First things first, au- 
tochthons had to be sifted from the Germans still to be expelled - I beg pardon of the civil servants offended by my lexical inattention - 'transferred,' 'repatriated' - of course, I am sorry. In the emergency census of 1946, all Germans remaining in Poland - and only they - were sternly required to reveal themselves to the authorities; the nationalities of the rest were of no importance. At the same time, local committees were formed in Upper Silesia and Mazuria (or the south of the former East Prussia) to identify autochthons. A couple of Silesian sentences, a Polish-language prayer or ditty, a Slavic-sounding family name, or the Christian name of a grandfather written down in Polish spelling sufficed to be handed a 'temporary document confirming the holder's Polishness.'

Over a million autochthons were identified and exempted from expulsion, even though some desired expulsion more than exemption, especially mothers with young children waiting for their husbands to return from Soviet prisoner-of-war camps. The Soviet and Polish authorities did not let them go home. They were German soldiers, so their place was in Germany. No Germans were to be tolerated in the new Poland. Civil servants, faced with the tears of the autochthonous wives of Wehrmacht soldiers, advised divorce. But for rural Catholic women divorce was an anathema. It was God who united them and their husbands in the holy bond of the sacrament of marriage that no man dares to sever.

Beautiful houses and lovingly tended farms were not to be neglected, especially when belonging to members of the Polish minority association in interwar Germany. Polishness had been their beacon, whose light had helped them survive during the worst years of Hitlerism, when Polish was banned and those speaking Silesian were cursed at and called names: 'You, Wasserpolacken!' Now, the war over, they had to make room for the newly arrived. High party officials and loyal security force commanders needed appropriate lodgings and a decent income. No tattered membership card of a minority organization was of help. The decision had been made. The stamp placed hard on a piece of lined paper torn out from a German school copybook sent the supplicant to the nearest German urban ghetto to wait for another cattle train to Germany.

Poles arriving in Upper Silesia saw autochthons as Germans, and their Silesian interlaced with German words as a dialect of the German language. To autochthons, the Poles from Lwów and Wilno weren't Polish, either, their speech reminding the unexpelled inhabitants in Opole and Katowice more of the cadences of the Russian language of the Red Army soldiers on their way to Berlin than of their own Silesian. It meant that repatriates had to be hadziaje, or Ruskies. But they were mistaken; these 'Ruskies' were Poles, and swiftly went up the party's ranks, state offices, schools and onto the managerial boards of nationalized factories.

Autochthons remained what they were, unsure of their fate for a long decade, until the mid-nineteen fifties, when their documents of 'temporary Polishness' were exchanged for internal passports, affirming that the holder was really a citizen of Poland, all official misgivings laid aside. Meanwhile, autochthons had diligently attended 're-Polonization' courses to master the basics of spoken and written Polish. Immediately after having established themselves in Upper Silesia, the Polish authorities enforced, with full severity, an unproclaimed ban on the German language.

German books and periodicals were gathered and systematically burnt in heating furnaces in the deep and damp cellars of offices, law courts and schools. In Groß Wartenberg (Syców), Neumittelwalde (Międzybórz) and Kreutzburg (Kluczbork), Lutherans' Polish-language hymnals, printed in the offending Fraktur, were also condemned to the flames. The watchful guards of fledgling Polishness wouldn't be fooled. Whatev- 
er was not in the 'normal script' had to be German by default. The Catholic Moravians (Morawzen) of Katscher (Kietrz) and Branitz (Branice) had made the same inexcusable mistake of printing their religious publications in the Slavic language of Moravian, but using Blackletter fonts. 'To the fire, to the furnace, with them all!' The German façade kept the new Polish Upper Silesia warm, and soon went up in smoke; gone was the ugly specter of the past not worth remembering, and forbidden to be recollected.

Liberated smoke clouded the vistas, but not the purpose. Prisoners, on a work detail, descended on cemeteries in orderly files with chisels, paint, tar and buckets of cement to remove and deface every single word and letter reeking of Germandom. Engineers pulled their hair out when their arguments failed to convince bureaucrats against removing technical specifications - mostly numbers and an odd word - from machines and devices on account of the 'odious German character' of these words.

Quite obediently and in most cases of their own volition, repatriates threw out anything with German letters on it from their new houses and apartments. Autochthons were 'ideologically uncertain,' and failed to see the point, and even worse, didn't see the writing on the wall, until a security officer paid them a visit and pointed to a tea towel with a German proverb on it, and to the offending label Salz on the salt shaker. 'Out with these to the rubbish bin!'

'Ja wohl,' they cried out in German out of fear, on a reflex in that high-sounding agreement conditioned in them by the Third Reich bureaucracy.

'What's this?,' the officer hissed and fumed.

'Sorry, we are, not repeat it in the future, promising we,' the squirming inhabitants replied in not-yet-correct Polish. They pleaded with the officer to escape the punishment liberally meted out by the long arm of the law.

In autochthonous villages and city quarters, silence ruled the day, and a hardly audible murmur of whispered words was kept inside households. As Poles they had to speak Polish and nothing else. Parents, fearful that their children might not otherwise count on any reasonable future, kept mum. The handful of Silesian words they managed to recollect were kept for plowing the fields and milking the cows. Children going to Polish schools were 're-Polonized' in no time, day by day growing more foreign to their own parents. The parents' tongues sworn into the knot of silence wouldn't speak of love, of the past. Not a word of explanation of what happened to my father's three uncles, who in the spring of 1945, on their daily way to work in a mine and in a nut and bolt factory, were rounded up by Soviet soldiers at the Gliwice railway station.

One of them, Onkel Teofil, starved and skinny, as if 'straight from a concentration camp,' staggered into my father's family house and collapsed. It was 1955. Ŏma and my father put him to bed. When he woke up next day, they fed him chicken broth with noodles. It took many long weeks to nurse him back to a semblance of himself. And while caring for him, there were so many baths and so much laundry to do; hardened camp lice just couldn't be got off him. Because he was so weak, he didn't say much, mostly murmured with Ŏma at night; Ŏpa (or Grandad), worn out by another day down at the bottom of a coal shaft, had no time for their idle talk. Eavesdroppers stalked outside the windows waiting for a careless word of German to be uttered, for a sentence denigrating the fraternal Soviet Union. His gaze empty and dull, Teofil died before Christmas.

Those who failed to keep their tongues in check found themselves dragged out from their houses and apartments, accused of 'malicious linguistic crime.' They became an anathema to Polishness. Poles cannot speak ill of Poland. It is not done. So many insidi- 
ous traces of undead Germanism were lurking in the shadows it was believed, waiting for an opportune moment when the Poles let their watchfulness slip. German could jump out and erase Polish words from newspaper columns, from the pages of books, and worst of all - from people's minds. The achievements of 're-Polonization' could easily be reduced to naught.

This possibility had to be prevented at all costs. For a first offence, linguistic offenders were usually let off lightly, with a fine and a cautionary note sent to their place of work. The repeated offence of talking in German was punished with the loss of employment, and for equal measure, the perpetrator's children were not allowed to go to school, any school in Poland. Hardened recidivists, who did not respond to the state's extraordinary leniency, had their apartments, houses and farms taken away. And as a last resort, to correct those who couldn't see for the immovable blinkers put on their eyes by evil Nazi propaganda, they were thrown into the special concentration camp for linguistic criminals in Gliwice. Not a single inmate left it not speaking Polish. Those whose ways couldn't be changed stayed in the camp for good, and in due course found themselves in the mass grave, fully quiet and silent in Polish. No trace of the camp is left, in what is now a sprawling housing estate of blocks of flats. Not the smallest of plaques commemorates the linguistic offenders, their bones six feet under the ground, but no tongues are left. All gone - success!

Fear ruled during the Stalinist years. The subsequent thaw was short-lived. The fashionable beatnik writer and fan of reactionary jazz from Warsaw, Leopold Tyrmand, visited Upper Silesia and, as he wrote in his diary, saw a foreign land. Polish books, Polish shop signs, communist slogans in Polish written in cut-out white square letters on long pieces of red cloth hung everywhere, Polish radio was relayed loud from communal speakers hung on lampposts, and Polish films were screened in the town's cinema. Yet, he was not able to strike up an intelligible conversation with an average person in the streets. Their words were familiar, but the meaning constantly eluded Tyrmand's ears. He defected to the West and settled down in Florida with a new American wife. The Everglades proved more familiar to him than Upper Silesia could ever hope to be.

The People's Republic of Poland was a good internationalist member of the Soviet camp of 'peace and progress,' and developed a fraternal relationship with the German Democratic Republic. Yes, Warsaw freely admitted, there were Germans in Poland, indubitable Germans, kindly invited to stay in Poland after the war's end on the account of their skills in engineering and agriculture management, so indispensable for the reconstruction of the country. They lived safely far away from the autochthons, in Lower Silesia and Pomerania. But most subscriptions to the German-language newspaper, the Arbeiterstimme (Worker's Voice), published in Wroctaw for the indubitable Germans, were snapped up in Upper Silesia and Mazuria. By the late 1950s the vast majority of the indubitable Germans had left for one of the two Germanys, but the demand for the newspaper grew inexorably. This didn't agree with the state plan of cultural work, so the Arbeiterstimme was closed down, because most of its officially eligible readers were already in the West.

Being Lutherans, Mazurs in the north-eastern corner of Poland were made feel even less Polish than autochthons in Silesia. A Pole had to be a Catholic in the atheist polity of communist Poland. Godlessness was a becoming quality only of newspapers and the classics of Marxism-Leninism. Workers and managers, peasants and PGR employees, city dwellers and villagers, anticommunists and regional secretaries of the party, all bap- 
tized their offspring and sent their children to their First Communion. In the communist decades more Catholic churches were constructed in Poland than ever before or since. Apartments for newlyweds were in acutely short supply - most people lived with their parents-in-law in the latter's apartment until they died, so now the already middle-aged 'newlyweds' could inherit it - but concrete flowed in abundance for the erection of yet another Roman Catholic temple.

To cut a long story short, in the nineteen seventies Mazurs followed in the footsteps of the indubitable Germans and trekked westward, leaving their villages and towns empty behind them, ready for repopulation by apartment-less couples from elsewhere in Poland. Autochthons from Upper Silesia also followed the Mazurs to West Germany, though not so many; life in Poland was too good for them, and, besides, there were ten-to-fifteen times more Silesians than Mazurs. Poland needed hard currency to prop up its economy and to pay back its debts to the West, and Warsaw was paid dollars only for highly calorific anthracite sold on world markets at dumping prices. Thus, autochthonous miners kept the Polish economy afloat. The party knew it well, so it rewarded them richly for their work. No shortages for them - all the sought-after consumer goods were freely available in special miners' shops. These shops were an exact copy of the shops for high party officials, hidden away from the hungry commoners' gaze behind yellow net curtains.

Why go then, if life could be so good under communism, to start everything from scratch in Rajch. The unruly muscle in the mouth was an important consideration as well. It had been tamed by school, by the conscript army, and by the security service to play the role of the tongue of a native Polish-speaker. The camouflage worn day and night became so perfect that it merged with its wearer, so that it became him, and he it. In only three per cent of autochthonous families, parents - mostly mothers - spoke to their children in German. But before sending them to school, around the time when the kids had turned five, their mums, all of a sudden, switched to Silesian, which could pass for Polish.

Never in my life have I seen friends, neighbors or families in Upper Silesia speaking German to one another, unless they were with relatives on a visit from West Germany. But they, too, in the midst of a party thrown in their honor, fuelled by Żytnia, the best Polish rye vodka, began speaking Silesian again. At long last they had really come back home.

Only the freest of the free could afford to disregard the straitjacket of the ideologically correct conventions imposed on the land and its inhabitants. Typically, lonely, middleaged and old men, abandoned by wives who went to Rajch - the husbands didn't want to - or hardened bachelors. Each of them was enamored of ethanol, state-announced 'parasites' who used every opportunity to avoid work. An odd hundred Deutschmark banknote sent to them cleverly hidden in a letter by their family from Rajch was more than enough for leading a sumptuous life for a whole quarter year. They drank and sang with their friends to their hearts' content. I heard the drunkards' songs in the morning while hurrying to school, and again in the evening when they still craved another dose of alcohol. These were German songs, which their mothers had sung to them in happy childhood, which they had sung in their youth. Militiamen and security officers pretended not to hear. What could they do? The times of forced labor camps and extrajudicial imprisonment that would have straightened out these wastrels and good-for-nothings, were over.

Mikhail Gorbachev talked perestroika ('reconstruction') and glasnost ('openness') in the Kremlin. In Poland the communist government engaged the democratic opposition in the Round Table talks. Who would split hairs over some drunkards; let them drink 
themselves to death. Nobody was sure what would happen next. After almost half a century under communism, autochthons, including the miners, knew they had had enough. Even before the Soviet bloc and communism itself went belly-up and the Soviet Union disintegrated, almost a quarter of a million autochthons had left for West Germany between 1988 and 1991. The vast majority were from the western half of Upper Silesia, or Opole Province, leaving villages and towns half-empty behind them.

Poland's first postcommunist government, after finally settling the matter of Poland's western frontier with the reunited Germany in the 1990 border treaty, became concerned that if nothing were to be done, Warsaw would have been left with a depopulated region on its hands. The mines were closing down; the miners, formerly cherished by the powers that be, were left destitute. The certainties of the previous age were gone. In 1989 the underground grassroots organizations of the German minority, established during the last decade of communism, gathered almost four hundred thousand signatures of people declaring their German nationality. Hundreds of pages of these declarations were deposited with the West German Embassy in Warsaw.

The event partly vindicated Bonn's 1982 claim of nearly a million Heimatverbliebene ('those [Germans] who remained in their homelands') in Poland, the vast majority of them in Upper Silesia (Reichling, 1986, pp. 62-64). Not all former German citizens and their descendants wanted to be Germans again. The West German policy of luring them across the Iron Curtain with free apartments, gratis language courses, Western-level pensions for work in communist Poland ceased with the end of the Cold War. West Germany had its hands full with East Germans moving over, and the disappearance of the Soviet Union opened the gates to the flood of ethnic Germans from the post-Soviet states, then rapidly going through cycles of economic tribulations, and terrors of political instability and war.

The German and the Polish governments preferred the Upper Silesian Heimatverbliebene to stay at home. To this end, after 1991, Bonn began issuing them with German citizenship and passports, without requiring the applicants to give up Polish citizenship and to move to Germany, which earlier had been the sine qua non condition. Although at that time neither German nor Polish law permitted dual citizenship, both sides were perfectly happy to breach the law in order to keep the autochthons in place. At the bus and railway stations in Opole and Katowice, kiosks catering to travelers stocked plastic protective covers with state coats-of-arms depicted on them for German and Polish passports in equal measure.

Buses began shuttling unemployed miners to and from Germany where they did seasonal work. In 1993 German passports became EU passports and Upper Silesian workers started moving further afield, to Austria, the Netherlands and even Luxembourg. By 2000 over a quarter of a million holders of such passports had picked up a smattering of German, enough to communicate with their employers. But German did not revive as a language of everyday conversation and good-humored banter in autochthonous - now already German minority - villages and towns. In 1990 and 1991 Warsaw officially recognized the German minority in Poland, with the full portfolio of typical entitlements to minority rights in education, culture and politics.

Despite the grumblings of the Polish majority, surprised at the sudden and unexpected appearance of the non-existent German minority, Warsaw welcomed German deputies and senators in Parliament. The membership of the German minority organizations ballooned to three hundred thousand. With the introduction of local government, German candidates, elected as mayors and aldermen, took over their towns and villages in the 
early 1990s, and at the turn of the twenty-first century, they seized control of the freshly constituted county administrations in Upper Silesia, and the regional one of Opole Province. With financial support flowing for the minority from the coffers of united Germany's budget, the German minority officials busied themselves with the installation of sewage and water systems. Cooperation with the Polish neighbors bloomed in minority localities.

But it was not good enough, not good enough at all. Germans dared to re-erect monuments dedicated to the memory of the fallen from their villages and towns during the Great War. The obelisks and sandstone plaques had survived in deep pits and under heaps of manure, hidden away from the sight of the removers of the 'German façade' in the latter half of the nineteen forties. Now they were back, and horror of horrors, brandnew ones were commissioned to commemorate in their home villages German soldiers who had died in the course of the Second World War. 'Unthinkable! Inexcusable!' texts on these monuments and place names, all were in German, and all that happening on Polish soil. How embarrassing and confusing to the true patriot. Wasn't it the case that freedom and democracy in postcommunist Poland was to be for Poles only?

'Real patriots' never failed to show their indignation at yet another breach of confidence and good manners perpetrated by the Volkswagendeutsche, or people who became Germans because, thanks to this decision they could count on improved income that would buy them a Volkswagen to drive, instead of a Polish Fiat. 'Monument wars,' as they became known in the press, broke out with an eerie regularity, every two or three years. The last one, in 2002, was famously stirred up in order to deflect the attention of the mass media from the regional governor and president in Opole. Subsequently, both were tried and sentenced to imprisonment for corruption and embezzlement on a massive scale.

Calm returned, things settled down, and it turned out that the German minority presented no danger to monolingual Polishness. The foreign researcher may open the official Statistical Yearbook of Poland, from which she will learn that contemporary Poland houses around six hundred German minority schools. From this it is easy to deduce that during the last two decades tens of thousands of Upper Silesian Germans have graduated from these schools and that German is alive and well in 'Opole Silesia,' as Opole Province is informally referred to.

In the latter half of the first decade of the twenty-first century this happy development was buttressed by the appearance of signposts with bilingual names of towns and villages. The Upper Silesians' Holy Mount can now be Sankt Annaberg again, not exclusively Góra świętej Anny. Now both the German and Polish names can brush shoulders together. From my village I can drive up the mountain, passing bilingual Zalesie / Salesche, Lichynia / Lichinia and Leśnica / Leschnitz. In Leśnica / Leschnitz, one can even correspond officially with the mayor and his officials in German.

But who does? The most tenacious from my father's generation, or the last ones who attended the first grades of German elementary school prior to 1945. At present they are pushing eighty, and are bound not to stay with us much longer. Now you can ask, 'What about the youngsters? The graduates of the German schools.' You are absolutely right, I owe you an explanation. As the saying has it, there are lies, damned lies, and statistics.

I sniffed the trail of this statistical lie, on a visit to the German minority elementary school in my village. I heard only Polish and Silesian spoken there. I asked a neighbor's daughter, 'How is your German?' She paused to think this question over, and replied in an unsure voice, 'I'm progressing. Foreign languages take so long to master.' Her grand- 
father who in 1944 as a Wehrmacht soldier had been rounded up with his division in Romania by the Red Army, and who then spent the following eight years felling trees in the vicinity of the Soviet city of Gorky (today, Nizhny Novgorod), had no patience for this German. He complained, 'They learn nothing, it's a disgrace, the teachers know no German.' He snorted angrily, 'How can they teach the poor kids anything?' 'Why don't you talk German to your granddaughter yourself?' I asked him.

'It's useless. Polish is all around. I can't speak kids' stuff, and what I remember is of no interest to them. It is a completely new world. I am a dinosaur, you know,' he chuckled.

I consulted the yearbook again. In the fine print at the foot of the table there were references to legislation, which I sought out. Soon enough it became apparent what the numbers game was about. Any school is a minority school where a minority language is taught as a mother tongue. And the law provides that teaching a language as a mother tongue can mean as little as devoting just two school periods (of forty five minutes each) to teaching this language per week; not a very high threshold. In today's Poland foreign languages are taught in all schools. Under this Act, every school in the country, with no actual changes or investment needed, could be declared a minority one, should the situation require it.

I scratched deeper under the surface. What is left to show after a couple of hundreds of millions of Deutsche Marks spent by Germany in Upper Silesia during the last twenty years? That is, apart from the sewage and water systems that serve everybody to the same extent, irrespective of her nationality and the language he may speak or curse in. Are there any schools where German is the medium of education? I had a look at the website of the Deutsche Bildungsgesellschaft (German Educational Society). It wasn't a promising start. The website was in Polish and had no German-language version (Niemieckie Towarzystwo Oświatowe, n.d.). I called them up in 2008. No clear answers were forthcoming; 'We are working on the problems... We are striving to improve the situation... Soon, a brochure with the data you are interested in will be published...'. I haven't received any in the four years that have elapsed since the phone call. Nor have I seen any trace of a German website.

I had better luck with the provincial Department of Education in Opole. They had no qualms about the situation, and even sounded proud to inform me that there were just three Polish-German bilingual schools in Racibórz-Studzienna, Raszowa (near Tarnów Opolski) and Solarnia. (In 2012 another one opened in Kędzierzyn-Koźle's peripheral district of Koźle-Rogi). They added that they were not really fully bilingual, meaning that more subjects and school hours were taught through the medium of Polish than German. It portends well for monolingual Polishness. At the present rate German will never be revived as a community language in Poland. No fear. The bottom line is the language of everyday life. The German minority can be recognized, but as long as they keep speaking Polish and Silesian, it is just about appearances. Going through the democratic motions for Germany and the world to see and nod approvingly.

What about the Ethnologue and its estimate of a quarter of a million German-speakers in Poland? How could they commit such an egregious error? Upper Silesia is not in the middle of the inaccessible Amazon rainforest. It is wide open for everybody to visit and see for themselves. The problem is that the Ethnologue sends teams to do field research in 'developing' countries; in the case of the 'developed world,' or the West, it relies on state-produced statistics, not batting an eyelid over how much data in a reputable yearbook may be massaged and falsified. Who cares? It is the West. It knows best. 
Maybe the Ethnologue rests its findings on the 2002 Polish census. In it, a hundred and two thousand people declared German nationality and German as their language of everyday communication within the family. One hundred and three thousand people declared the German language, but Polish nationality. Lastly, fifty-one thousand declared German nationality, but Polish as the language they talk in to their relatives. The three numbers add up to slightly more than a quarter of a million, and correspond closely to the number of Polish citizens who are also holders of German passports. But even when taking the declarations at face value, the self-declared speakers of German amount to just around two hundred thousand.

Why do they declare German as their family language when German words do not audibly cling on in a single locality, however tiny, in today's Poland? After the 'humane and orderly transfers' in the first half of the nineteen forties, followed by half a century of 're-Polonization,' and the subsequent two decades of democracy with 'full respect paid to the observance of minority rights,' almost half of the Germans and people of German decent living in Poland are afraid to admit they are Germans. Their parents, they themselves, their siblings and their children were incarcerated, maltreated, shouted at in school and in the army, beaten up by peers, discriminated against, barred from traveling to or leaving for West Germany, jeered at and ridiculed for their inability to speak in 'correct Polish,' for not being Polish enough. Being an autochthon was a curse. Who knows what being a German in free Poland may mean? You need to be wary. As the past shows, democracies can morph into authoritarian and totalitarian regimes in the brief span of a couple of years. And then what happens when the census returns land in the lap of an eager team of patriotic and nationally-minded social engineers?

It is safer to declare a language you may not even speak, your ancestral tongue of parents and grandparents, instead of committing to paper your nationality that one day may become the justification for a harsh sentence read out to you in a kangaroo court. The parallel breakups of Yugoslavia and its language of Serbo-Croatian that cost well over one hundred thousand people their lives and sent waves of millions of refugees are a hard and cold - like the metal of the muzzle of a submachine gun - reminder that the black twentieth century may not be over yet.

But where can the visitor hear German spoken by many people in the same place, by a community? There are indeed such places, namely, churches in German minority towns and villages. The Opole Bishop Alfons Nossol (who received the title of Archbishop ad personam for negotiating, in 1998, the successful signature of the Catholic-Lutheran declaration that from the theological point of view - though not institutional - ended the halfa-millennium-long schism between the Lutheran and Roman Catholic Churches), immediately after his consecration in the summer of 1977, introduced German as a compulsory subject in the diocesan divinity seminary in Nysa. A brave move. Since 1945 the informal ban on this language had meant that not a single educational institution had been allowed to teach it in the areas inhabited by and associated with the autochthons, or in Upper Silesia and Mazuria. That is why, when the first-ever fully-fledged university was founded in Upper Silesia (with the confusing name of the University of Silesia, though the historic capital of Silesia is Wroctaw located in Lower Silesia) in 1968, its Department of Germanic Languages had to be located outside the historic region, in Sosnowiec.

Earlier, in 1955, German was introduced in a Katowice secondary school, named after the first East German President, Wilhelm Pieck. Autochthons were barred from attending the institution, since its role was to produce loyal German-speaking cadres of real Poles 
for developing 'fraternal socialist cooperation' with East Germany. In reality it was Bishop Nossol who breached this anti-German monopoly of Polish monolingualism in Upper Silesia. As remarked above, he revived the tradition of bilingual German-Polish teaching in the Breslau divinity seminary, which had lasted from 1846 until 1945, when all things German were to be removed in the lands east of the Oder-Neisse line.

In the middle of the nineteenth century the Catholic Church, then responsible in Prussia's Upper Silesia for the spreading network of elementary and secondary schools, had realized that teaching Slavic-speakers through the medium of (to them) incomprehensible German defied the purpose of education. They settled on Polish as a language with dictionaries, grammars and a canonical translation of the Bible, as being close enough to the Slavic speech of their faithful. The question of translating Holy Writ into their Silesian vernacular, broached briefly in the eighteen forties and again in the eighteen seventies, was abandoned due to costs and the absence of dictionaries and grammars of Silesian.

In the first years of elementary school, teaching for Silesian-speaking children was provided in Polish, then it became bilingual in Polish and German, before switching fully to German in secondary school. Obviously, few at that time progressed beyond elementary education. In 1873, two years after Prussia had founded the German Empire, Polish-medium schools disappeared in Upper Silesia. Polish survived in church as the language of songs and pastoral services. At home and in villages people spoke Silesian, to civil servants and teachers they spoke German, while in church, hymns were sung in Polish. This trilingualism continued until the 1922 division of Upper Silesia between Germany and Poland; Berlin and Warsaw were bent on making their parts of the region monolingual in German and Polish respectively. The reincorporation of the entirety of Upper Silesia into Germany during the Second World War nullified most of the advances of Polonization. Hence, 're-Polonization' was needed after 1945, though actually it was re-Polonization only in the prewar Poland's section of Upper Silesia, but straightforward Polonization in the interwar German part of the region.

Bishop Nossol's decision to revive and respect the tradition of multilingualism in Upper Silesia prepared hundreds of priests who in secret, on a one-to-one basis, talked to their faithful in German and listened to their confessions in this language. When communism fell, and the orthodoxy of national monolingualism that had earlier ruled the day was softened a bit by democracy and respect for human rights, in 1989 Nossol celebrated the first official German-language Mass in post-1945 Poland in the shrine on the Holy Mount of Upper Silesia, Góra świętej Anny. He did it against the Polish primate's and hierarchs' vociferous opposition. They could do nothing, because Pope John Paul II himself gave Nossol his consent. He paid for this 'insubordination' to Polish Catholicism by being studiously overlooked when suitable archbishopric posts appeared. The papal nuncio, on the advice of the Polish Episcopate, refrained from forwarding the name of Nossol to Rome for consideration for these posts.

Since the turn of the nineteenth century, German- and Polish-singing groups of pilgrims had walked to the shrine in Sankt Annaberg, year after year. The end of World War Two cut this tradition short, but not permanently, now that bilingualism is back. In the nineteen nineties German and bilingual masses appeared in every autochthonous church, not infrequently to the dismay of 'real Polish' parishioners. To alleviate the fears of 'reGermanization,' German masses were moved to inconvenient morning or late afternoon hours, though this was a small price to pay for these faithful, who for over forty years 
hadn't been able to pray together in the language in which their first pater noster had been taught to them.

In churches, German revived as the language of local communities during the newly permitted minority masses for autochthonous Germans. After 1989 German became a new church language in Upper Silesia, as Polish had been in the region before 1945 (with the brief and tiny interlude of interwar Poland's section of Upper Silesia). But ecclesiastical German was not destined to stay for long. Those longing for hymns in this language were already old when their wish was finally granted. By the beginning of the twenty-first century most had died. Subsequently, the demand for German masses has lessened, and one by one they have been removed from churches, biology lending a helping hand to Polonization.

The story of forced Polonization and of the ban on German in communist Poland is increasingly becoming one of the myriads of grains from which the ever-changing kaleidoscopic tapestry of the past is composed. It changes depending on who is looking and asking. To some, the ban and the program of Polonization are just a myth constructed for the sake of the German minority leadership by scholars beholden to German funding organizations. This, then, is a suitable place for the following story.

In the early nineteen nineties, in an Upper Silesian town an old gentleman was approached by a doctoral candidate from Germany, eager to probe into what the 'true history' of the German language was in the region during communism. He broached the subject in a conversation in the 'school Polish' he had acquired at the Summer School of Polish Language and Culture at the Jagiellonian University in Cracow. The distinguished gentleman listened, though he knitted his brow momentarily when he was referred to as an 'autochthon.'

'I am a German,' he declared, to clarify the point. 'Only the government talked about "autochthons". All of us were slandered with this term by the communists. We knew who we were. But it was better to keep it to yourself.'

'I see,' the student nodded, not knowing what to make out of this piece of field information, but sure that pursuing the line could make his informant angry, thus leading to a premature end to the interview. 'Then, what about the German language?'

'What about it?'

'I read in books published by the organizations of the expellees in West Germany that it was forbidden to use this language in Poland's Upper Silesia during the communist years.'

'Well, there was no ban. We're all Christians, are we not?'

'I don't understand.'

'When I was taught the Catechism, it stated there that every human being has free will, of which he cannot be deprived.'

'Do you mean that you had no problem speaking German in Poland under communism?'

'Of course not,' said the impeccably dressed gentleman, who was wearing a threepiece suit, switching from Silesian into German. 'I always spoke as much German as I wanted, to my heart's content. But every eight or twelve years, sadly, I needed to change my interlocutors.'

'Did they die? Were they imprisoned?,' the student helpfully proposed.

'No,' replied the gentleman. 'I always spoke German to my dog.' 
In the summer of 1997 after the two-week-long 'monsoon' of continuous rainfall in the basin of the Carpathians and the Sudeten Mountains, an unprecedented massive flood hit the cities and towns located along the Danube, the Elbe and the Oder, across the length and breadth of Central Europe, in Romania, Hungary, Austria, the Czech Republic, Poland and Germany. It inundated entire city centers, residential and industrial areas, parks, roads and what have you. Devastation was rife. The lives of hundreds of thousands lay in ruins.

The disaster, however, was a blessing in disguise. In postcommunist Poland, still drab, grappling with the legacy of the decades of neglect and stagnation, some of the cities and towns that had now been further ravaged by the elements seized the chance to reinvent themselves as European metropolises. Wrocław is the prime example. Between February and May 1945, the collapsing Nazi regime had made Breslau into a 'fortress,' an islet of German-held territory fully surrounded by Red Army troops. The sole link with the rest of Germany was secured by the air bridge, for the sake of which entire sectors in the center of the city were flattened to make room for runways. In communist Poland, the city, now renamed Wrocław, languished in obscurity, its ruins quarried well into the late nineteen fifties for trainloads of bricks which were used in the reconstruction of Warsaw, itself razed to the ground in 1944 by the German occupiers. Wrocław was still perceived to be an enemy city. Polish repatriates from Lwów didn't feel there at home. Every repair job in an apartment or on a building seemed to uncover German shop signs and inscriptions painted in black and elegantly slender Fraktur. When old insulation was removed from the wall cavities of buildings, the floor would be sprinkled with disintegrating German newspapers.

Traces of Germandom looked out from every nook and cranny, making the newcomers uncomfortable. It was an acute denial of the communist party's claim on the primordial Polishness of the city. The same story repeated itself across all the former German territories east of the Oder-Neisse line. In Gdańsk, Szczecin and Opole. But the decades of patient removing, pouring the concrete of cubistic internationalist socialist architecture in the city centers made people forget, made the cities forget themselves.

When I taught at the University of Opole, with each group of freshmen entrusted to my care, as a prod to make them think, I asked where they and their families came from. Most were from Opole, so predictably enough they claimed the city as the place of origin of their families. 'So your families lived here before the war?' I persisted.

'Yes, they did,' was the quick and honest answer.

'So did they speak German?'

'No, not at all, the language was Polish,' they maintained. 'They were Polish like us.'

'But Opole was then a city in Germany. It was called "Oppeln".'

Doubt clouded their brows; the students were at a loss. I proposed they enquire of their parents and grandparents about the past, and that they should let me know the following week what they had learned. They returned to class next time full of stories that were a revelation to them. 'My parents were born in Opole, but granny came from Wilno, and granddad from Lublin.' 'Mine from Kalisz and Nowogródek.' 'And mine from Pińsk and Suwałki.' 'From Kraków and Grodno,' 'From Brześć and Łódź,' a roll call of villages, towns and cities of interwar Poland, today either in the eastern half of Poland, or further east in Lithuania, Belarus and Ukraine. The sealed gate of amnesia suddenly flung wide 
open, an amnesia imposed by school and not disturbed by adults. The adults were rightly wary that their children could destroy their life chances if they started relating family stories that were so blatantly in breach of the 'true history' meticulously gleaned from the school textbook for tests and examinations.

With a raised hand I silenced them, 'Whose family is then originally from Opole, I mean "Oppeln"?' No one was forthcoming. I had no comment to add, this resounding Zen-like clapping of the single palm being the most precious lesson in itself.

I thought a fledgling scholar would know better. Once, a doctoral student from the University of Warsaw invited me for a cup of espresso (then a stunning novelty in the late-nineteen-nineties Opole) to talk over her research plan. Exquisitely dressed and relaxed in her unprovincial manners, the beautiful young woman with the shock of auburn hair was a veritable image of worldliness, worlds away from the drab monolingual patriotism of the beleaguered outpost of Polishness in Opole. She wanted to research the Polish national movement in interwar Opole by looking at appropriate documents in the local state archive. Documents in Polish. 'Don't you know German?,' I asked.

'French, English and Russian, I know,' she replied with an endearing little laugh. 'You know, all the war films in my childhood. Evil SS-men and Wehrmacht soldiers. At school I learned that German is an ungainly and harsh language, unpleasant to listen to, and grating on the palate to speak.'

'Reading a bit in German would help with your research.'

She kept folding a napkin nervously in her hand, 'Maybe I will attend a language summer course in Germany in a year or two for another project.'

'But all the documents in the archive from before 1945 are in German. It was the sole language of official business then. In Oppeln, as elsewhere in Germany.'

'Oh,' she exclaimed, 'I didn't know.'

In one ditty, Opole is described with a playful adjective o-polski. Opolski without a hyphen following the ' $\mathrm{O}$ ' is the standard Polish adjective formed from the name of the city. The tiny hyphen makes a gulf of difference, changing the word into almost a confession of love, 'Oh! You are so Polish!' Similarly, in the heavily falsified Polish census of 1931, interwar Poland's section of Upper Silesia was declared the most Polish of all the Polish regions. More Polish than Warsaw, than Cracow. The insubstantial façade of Germandom evaporated into the thin air of Berlin's delusions about some Germans in Katowice. During the war the Poles of the Polish section of Upper Silesia were Germans again. In communist Poland they wanted to leave for West Germany, but were rarely permitted to. 'It's enough, no need to remember that. Let's have a stroll, the weather is nice this May.' My then girlfriend reacted so, in a very English way, to my over-intellectualized talk about the past. She placed her slender fingers on my lips, 'Hush!,' said she, and kissed me.

But after 1997, in the fervor of the post-flood reconstruction, Wroctaw made peace with its past, however ideologically unsavory. It became reconciled to having been Breslau before 1945. Merchant houses, churches, fountains, and cobblestoned streets were refurbished back to their prewar glory, down to the manhole covers complete with Fraktur lettering in German. The mayor only laughs when cheap airlines announce flights to his city as departures for some 'Rock-lo,' which sounds like a ski resort in the midst of the Rocky Mountains. 'Let it be, let them say it as they can, we are in united Europe now, so it's all right, as long as passengers know where they are headed for,' says he, reclining in a big and comfortable leather armchair, an image of newly-acquired EU savvy. No need for him to cloak himself and his city in the worn-out banner of monolingual Polishness. 
But Wrocław is monolingual, with just a handful of aged indubitable Germans huddling in their Lutheran church. Most of them married Poles and decided to stay when the time had come for them to go west after 1956.

In Opole it could have been different; the headquarters of Poland's German minority organizations are located in this city. Its main street, ulica Krakowska, is a literal translation from the German Krakauer Straße for 'Cracow Street.' It is part of the old medieval route from the Black Sea, running through Lviv and Cracow to Opole, and then onward to Wrocław, Erfurt, Frankfurt am Main and Paris. How many languages have been resounding alongside it? Through the windows of how many faiths has God has been praised, or cursed? But because of the German presence indelibly associated with the autochthons (who one day are Poles and another day Germans), Opole has to be content with a safe generic past, almost a plastic past. Somewhat European, somewhat medieval and renaissance, without - for God's sake - any reference to the Oppeln past inscribed in Fraktur. The Opole old town, renovated after the 1997 flood, is spick and span, its old veneer an imaginary past, though not too vehemently pushing the myth of primordial Polishness. The nominal Polishness of the generic past is expressed through plaques in memory of a pre-1945 Polish minority organization, a Polish cooperative bank and a newspaper, liberally hung on the old buildings which housed their headquarters. So, there is precious little to show for all the eight centuries of Oppeln.

Yet, an axis mundi anchoring Opole's inhabitants to their city was missing. The lack was painfully felt. At long last they wanted to feel at home here, in their own city. In 1970 it was high time for an iconic monument celebrating Opole's Polishness. That was the year of the twenty-fifth anniversary of the 'defeat of fascism' and of the 'liberation of Opole.' 'Liberation from whom?,' I kept asking myself, and the only answer I could think up was 'from Oppeln'. After emptying Oppeln of its inhabitants in 1945, an entire new generation - Polish through and through - had come of age in Opole by 1970. The chosen monument was a gigantic crudely hewn squat 'Opole (or rather "Oh-Polish") Nike,' mounted on the unstoppable bison of Polishness, her right hand raised aloft and breasts thrust forward to a bright socialist Polish future.

The irony was that the last wild European bison was shot in Poland in 1919, a year after the nation-state had been founded. Interwar Poland financed a program of pairing fifty-odd captive individuals lingering in Europe's zoos in order to reintroduce the animal to the wild. In the late nineteen thirties, sixteen bison roamed the Białowieża primeval forest, split today between Belarus and Poland. The population of the proudly labeled 'our Polish żubr' stands today at over a thousand, and in airport duty-free shops foreigners are treated to the Polish specialty of Żubrówka, or żubr-vodka, which in Kyiv morphs into the Ukrainian vodka, Zubrivka. This vodka scented with a blade of buffalo grass travels well, and has a chance of becoming the iconic alcoholic drink in northern Central Europe, as whisky is in the British Isles.

In Opole the żubr of the German language is much closer to ultimate extinction than the Polish language had ever been in Oppeln. The sole publicly visible sign of the tenuous survival of the former is the bilingual, German-Polish weekly Wochenblatt. It caters to the German minority with its Polish-language articles and a small rubric in Silesian, while texts in German are read by only a few, other than subscribers in Germany. In 2010 the newspaper's new editor had to be imported from there, too.

Likewise, the sole remaining German minority deputy in the Sejm, or the lower chamber of the Polish Parliament, Ryszard Galla, could not acquire German at home. He was 
born in Wroctaw in 1956 and started his adult life when dog owners were free to speak German only to their pets, carefully, out of earshot of the eavesdroppers who were leisurely strolling on duty through meadows, forests and fields. In free Poland Galla progressed patiently through the ranks of minority-dominated commune and county local government administrations until he reached the regional assembly of Opole Province. In 2001 he sparred with the then leader of the German minority, Heinrich Kroll, for a mandate in the Sejm, but lost on account of his shaky command of German. Most of the devoted electorate of the German minority are the oldest generation who know this language well, though they have had no opportunity to speak it much after 1945. The time was ripe for a generational change, but first Galla had to learn German to a level adequate for reasonable communication with his rapidly aging electorate and to liaise with the German ministries that grant support to Poland's German minority. He won a seat in the following parliamentary elections of 2005.

In no time, the inhabitants of Opole christened the żubr-and-Nike monument as the homely 'Woman on the Bull.' It is located just across the street from the place a statue of Kaiser Wilhelm I had stood in a small park until it was torn down in 1945. With Oppeln already transformed into Opole, the old axis mundi of pre-Polishness times was slated for extinction. The gestation of its Polish counterpart took longer than 'engineers of souls' predicted, but at long last the Woman on the Bull anchored footloose inhabitants to Opole as their city. Oppeln was finally erased from living memory. But twenty years later, Germans were back. The patriots' secret fear that autochthons were none other than 'crypto-Germans' seemed vindicated by Warsaw's recognition of the German minority in 1991.

The Woman on the Bull was crumbling; the shoddy workmanship showed. As hastily as the monument had been built, just as quickly it was now disintegrating, exposed to the relentless elements. Communist propagandists of success were famous for lavish celebrations during the official opening of a brand-new road or viaduct that the following day had to be closed for a year-long renovation. There was no time to lose, and in 1993 the monument's endangered structure received its much-needed revamp.

Few noticed a non-structural change in the wording on the information plaque on the pedestal. Originally this plaque announced it to be the 'Monument in Honor of the Fighters for the Freedom of Opole Silesia.' After 1993 it became the 'Monument in Honor of the Fighters for the Polishness of Opole Silesia.' In the Polish inscriptions the number of words remained exactly the same, Polskość ('Polishness') replacing Wolność ('Freedom'), the new word just a single letter longer. There was no public discussion on the change. Newspapers failed to record it. State offices, when questioned about who took the decision, go mum. Inhabitants of Opole just shrug and see it as a commonsensical correction, not requiring any explanation. 'Otherwise,' Radek - an acquaintance of mine living in the city - let me know, surprised by my naivety, 'if the old inscription had been kept, it would have looked as if the monument were commemorating the freedom re-gained by Germans in Opole Silesia. We don't want this, do we?' I preferred to remain silent.

Not that the aforementioned freedom did much good for the German language.

Opole City and Opole Province celebrate themselves as beacons of multiculturalism (Kwiatkowski, 2011; "Wielokulturowość - bogactwem Europy”, 2011). Public relations specialists advise this approach, because it helps attracting tourists and investment. And where can a potential investor be taken for a stroll to show him (invariably, 'him,' unfortunately) how lovingly and painstakingly multiculturalism is cultivated in Opole? Well, it is 
better to have a glance at the Woman on the Bull from afar; translating the words on its plaque could be unhelpful. But nearby, in a picturesque wooded nook on the bank of the Oder (I beg your pardon, of course, I mean the Polish 'Odra'), the state-of-the art, steeland-glass futuristic building of the municipal library opened in 2012. Its façade is adorned with languages. Poems lend themselves to this task most easily. On closer scrutiny, the intrepid flâneur can discover that the fashionable adornment (or is it adorement?) is supplied, courtesy of a poem by Edward Stachura and its English translation.

Why Stachura? Why English? It's easy. This neo-Romantic poet was born in France and spoke French alongside Polish; that explains the English translation. He lived in Central Poland, finished secondary school in Gdynia on the Baltic Sea, pursued his university studies in Lublin and Warsaw, and settled down in the Polish capital. So all his life he lived in Poland, as far away from Upper Silesia as possible. This explains his poem on the library.

You may shake your head that what I am saying doesn't add up. I'm just repeating what I see; it all makes perfect sense to those who live today in Opole. After the successive coming and going of the German and Polish façades, the time has come for assuming yet another façade, true to globalization and forward-looking, the mantle of English shared with scores of polities across the world. Polish is an old-fashioned language, spoken in just a single country. The idiom doesn't allow any other into its sacred courtyard of the national polity, and has no wish to overstay a courtesy visit in another state. Cuius regio, eius lingua, remember?

Following Poland's accession to the European Union, two million young Poles (and counting) - including autochthons, or German minority members - have left for Britain and Ireland. They are the avant-garde of a future EUpoland - Poland in EUroPe, EUroPe in Poland. But it can't be that the most important library in Opole wouldn't claim a strain of the past for its heritage, precariously staking all its hopes on the not-yet-materialized future. You're right. In communist Poland I attended a secondary school with four hours of English per week. So in the past, in agreement with the definition of minority school espoused nowadays in the Polish Statistical Yearbook, before 1989 there were hundreds of EUnglish minority schools across the country, and not a single German one then. Now EUnglish is taught in each and every single Polish school, so all of them - tens of thousands - cater to the EUnglish minority.

'Go(o)d(s), Honor, EUtherland,' ${ }^{5}$ as EUpoles shout at the top of their lungs.

Koto ('wheel', see German Rad for 'wheel' and 'bicycle') and rower are Silesian and Polish for 'bicycle.' Dej se karnōnć and daj się przejechać are, respectively, Silesian and Polish for 'let me ride your bike.' Ŏma is Silesian 'granny' (derived from German Oma), which is babcia in Polish.

Guten Morgen - German for 'good morning,' szczynść Boże - Silesian for 'God bless you.'

Bóg, honor, ojczyzna ('God, honor, fatherland') - the most important Polish nationalist slogan, which gained its current elevated status already in the nineteenth century. 
Badanie Socjologiczne Mniejszości Niemieckiej w Polsce. (2010). Opole: Dom Współpracy Polsko-Niemieckiej.

Isztok, M. (2010). Zapomniany Pogrom Oświęcimski. Retrieved July 23, 2012, from www.stowarzyszenie.romowie.net/index.php/czytnik-aktualnosci/items/zapomnianypogrom-oswiecimski.html

Kwiatkowski, J. A. (2011). Wielokulturowość Śląska Opolskiego. Retrieved July 26, 2012, from najlepszeimprezy.eu/index.php/ext-regiony/item/1288-wielokulturowosc-slaskaopolskiego.html

Niemieckie Towarzystwo Oświatowe. (n.d.). Retrieved July 25, 2012, from http://www. dbg.vdg.pl/de/index.php

Poland: Languages. (n.d.). Retrieved July 22, 2012, from http://www.ethnologue.com/ show_country.asp?name $=\mathrm{pl}$

Reichling, G. (1986). Die deutschen Vertriebenen in Zahlen (Part I: Umsiedler, Verschleppte, Vertriebene, Aussiedler 1940-1985). Bonn: Kulturstiftung der deutschen Vertriebenen.

Wielokulturowość - bogactwem Europy. (2011). Retrieved July 26, 2012, from www. opolskie.pl/serwis/index.php?id=199\&idd=5525 